\title{
Inflammatory process as an etiological and prognostic factor of stroke and the goal of potential treatment strategies
}

\author{
Proces zapalny jako czynnik etiologiczny i rokowniczy przebiegu udaru mózgu \\ oraz cel potencjalnych strategii leczniczych
}

Agnieszka Kraśniej-Dębkowska, Maciej Śnieżyński, Anna Członkowska

Institute of Psychiatry and Neurology, 2nd Department of Neurology

\section{ABSTRACT}

Objective. Inflammation is the body's natural defence mechanism against factors that damage its tissues. However, if it lasts chronically, it may adversely affect the body's homeostasis. Inflammation is not only a long-known risk factor for the development of atherosclerosis and its complications, but also develops brain tissue damage in the course of ischemic stroke or intracerebral haemorrhage, leading to even greater damage. In addition, the immune system functions are impaired, which increases the risk of infection.
Literature review. Drugs that can reduce the risk of stroke by inhibiting vascular damage and modifying the inflammatory process in the central nervous system, including counteracting the risk of infection, have become the subject of many experimental and clinical studies on strokes. Such drugs include canakinumab, human recombinant interleukin-1 receptor antagonist, colchicine, fingolimod, siponimod or natalizumab.

Conclusions. Considering all available research results, the therapeutic pathway using anti-inflammatory drugs has a high potential; however, the complications associated with evoked immunosuppression in patients should be kept in mind. The paper presents a review of the literature on the role of the inflammatory process in the pathogenesis of stroke as well as related therapeutic options.

\section{STRESZCZENIE}

Wstęp. Zapalenie jest naturalną reakcją obronną organizmu na czynniki uszkadzające jego tkanki. Jeśli jednak trwa przewlekle, może niekorzystnie wypływać na homeostazę organizmu. Zapalenie jest nie tylko znanym od dawna czynnikiem ryzyka rozwoju miażdżycy i jej powikłań, ale rozwija się także po uszkodzeniu tkanek mózgu w przebiegu udaru niedokrwiennego czy krwotoku śródmózgowego, doprowadzając do jeszcze większego uszkodzenia. Ponadto w przebiegu udaru dochodzi do zaburzeń funkcji układu immunologicznego, co zwiększa ryzyko infekcji. 
Przegląd piśmiennictwa. Przedmiotem wielu badań doświadczalnych i klinicznych nad udarami mózgu stały się leki, które mogą zmniejszyć ryzyko udaru poprzez hamowanie uszkodzenia naczyń, modyfikować proces zapalany w ośrodkowym układzie nerwowym, a także przeciwdziałać ryzyku infekcji. Do takich leków należą m.in. canakinumab, ludzki rekombinowany antagonista receptora interleukiny-1, kolchicyna, fingolimod, siponimod czy natalizumab.

\section{Introduction}

The inflammatory process is an innate, physiological defence mechanism of the body against factors damaging its tissues. The factors damaging to the body are eliminated, dead tissues are removed and the healing process is accelerated in acute inflammation due to changes in blood flow, increased vascular permeability and activation and migration of white blood cells to the damaged tissue. However, if the inflammatory process is chronic, excessive stimulation of the immune response can lead to hypersensitivity reactions or the development of autoimmune reactions (Całkosiński et al., 2009). Numerous experimental and clinical studies draw attention to the role of inflammation and immunological reactions both in the pathogenesis of atherosclerotic vascular damage and in the development of stroke focus. The brain damage itself also causes immunological suppression leading to post-stroke infectious complications. Modulation of the inflammatory response is now considered a promising strategy in stroke prevention and treatment. This paper will discuss these issues and ongoing clinical trials.

\section{Inflammatory process in atherosclerosis}

Atherosclerosis as a disease of medium and large arteries was initially associated mainly with dyslipidemia and accumulation of cholesterol deposits in the intima of these vessels. It was only in the early 1970s that Russel Ross put forward the hypothesis that atherosclerosis is an inflammatory process which is the response of the vessel wall to the damage (Ross, 1999). Current data show that regardless of which process was the primary trigger, inflammation and dyslipidemia coexist from the early stages of atherosclerosis until the rupture or erosion of atherosclerotic plaques and related cardiovascular complications. Hypercholesterolaemia initiates the inflammatory process, but eliminating lipid disorders is not enough to inhibit atherosclerosis. In addition, as many as $50 \%$ of patients with atherosclerosis have no initial hypercholesterolemia. Inflammation can, therefore, be a lipid-independent factor initiating the process of
Wnioski. Biorąc pod uwagę wszystkie dostępne wyniki badań, ścieżka terapeutyczna z wykorzystaniem leków przeciwzapalnych cechuje się dużym potencjałem, jednak należy pamiętać o powikłaniach wiążących się $\mathrm{z}$ wywoływaną u pacjentów immunosupresją. W pracy przedstawiono przegląd piśmiennictwa dotyczącego roli procesu zapalnego $\mathrm{w}$ patogenezie udaru, jak również możliwości terapeutycznych.

atherosclerotic plaque formation. It has been shown that low-intensity chronic systemic inflammation, measured with C-reactive protein (CRP) concentrations, is associated with an increased risk of atherosclerosis (Manduteanu and Simionescu, 2012).

Low-density lipoproteins (LDL) are the main fraction of cholesterol transported from the lumen of vessels to tissues. In areas susceptible to atherosclerosis development, such as arterial bifurcations and origin points of smaller arteries, there may be an accumulation of LDL in the subendothelial space in the intima, especially in patients with elevated LDL and decreased levels of high-density lipoproteins (HDL) in the serum. After leaving the lumen of the vessel, the LDL molecules undergo various modifying processes, among which oxidation is predominant (Ercan et al., 2014). Oxidised LDL molecules (Ox-LDL) by their effect on endothelial cells inhibit the activity of nitric oxide synthase 3 (NOS-3), stimulate endothelin 1 production and increase its vasoconstrictive properties, activate lectin-like oxidised low-density lipoprotein (LOX1) membrane receptors for oxidised LDL, increasing the activity of the angiotensin-converting enzyme and its AT1 receptor, and directly stimulate the proliferation of smooth muscle cells, thus increasing the volume of atherosclerotic plaque (Pasierski and Andziak, 2004; Kranzhofer et al., 1999).

The endothelial cells together with the collagen basement membrane constitute a barrier between the lumen of the vessel and the other layers of its wall. Through the secreted substances, the endothelium controls the permeability of the vessel wall for blood cells, modulates the tension of the smooth muscle of the vessel wall, influences the processes of coagulation and fibrinolysis, and participates in the regulation of inflammatory processes. The development of an inflammatory response, preceded by the activation of endothelial cells, occurs not only in the course of hyperlipidaemia, but also in the course of other diseases such as hypertension, infections (especially of Chlamydophila pneumoniae aetiology), diabetes, or obesity (Libby et al., 2002; Kranzhofer et al., 1999; Yudkin et al., 1999).

In activated endothelial cells, the nuclear factor kappa B (NFkB) is released. This increases the expression 
of adhesion proteins, such as E-selectin, vascular cell adhesion molecule 1 (VCAM-1) and monocyte chemotactic protein 1 (MCP-1) enabling migration of inflammatory cells (mainly monocytes and lymphocytes) into the vessel wall. Monocytes under the influence of macrophage colony stimulating factors produced by endothelial and smooth muscle cells, such as M-CSF (macrophage colony stimulating factor) and GM-CSF (granulocyte-macrophage colony stimulating factor), are transformed into macrophages. Macrophages show high expression of scavenger receptors and by absorbing Ox-LDL, they take the form of foam cells, reducing their harmful effects on endothelial and smooth muscle cells. Over time, however, free cholesterol crystals are precipitated in the lipid-overloaded foam cells, which leads to the cells breakdown and accumulation of cholesterol deposits extracellularly; thus, the lipid core of the atherosclerotic plaque is formed. In addition, macrophages stimulate the expression of adhesion molecules on endothelial cells, intensifying the inflow of other inflammatory cells to the vessel wall and stimulating the migration of smooth muscle cells from tunica media to tunica intima (Banach et al., 2004). Smooth muscle cells synthesise collagen and proteoglycans, creating the so-called fibrous cap, which stabilises the atherosclerotic plaque.

Activated endothelial cells affect not only white blood cells, but also platelets. They influence the aggregation of platelets and initiate an extrinsic blood clotting pathway through the expression of the tissue factor. Thrombin is not only an important element of the coagulation cascade, but also a strong pro-inflammatory factor. It stimulates the recruitment of monocytes by increasing the expression of MCP-1 protein, activates smooth muscle cells through the type-1 protease activated receptor (PAR-1) and, in addition to adenosine- 5 '-diphosphate (ADP), is the strongest platelet activator causing their degranulation (Jarząbek et al., 2015; d'Audigier et al., 2015). Clots are most often formed on the surface of the ruptured plaques, more rarely on the surface of the eroded plaques (exposed basal lamina due to endothelial cell damage). In unstable atherosclerotic plaques, the process of neovascularisation and haemorrhage into the interior of the plaques are often observed. The inflammatory cells mentioned above, i.e. T lymphocytes and macrophages, are one of the main factors which cause plaque destabilisation. $\mathrm{T}$ lymphocytes secrete interferon $\gamma($ IFN- $\gamma$ ) to inhibit collagen synthesis by smooth muscle cells and stimulate their apoptosis. Macrophages produce metalloproteinases (collagenase, gelatinase, stromelysin) to destroy the fibrous cap of the atherosclerotic plaque (Amento et al., 1991). These processes are shown in Fig. 1.

The presence of an inflammatory reaction in human atherosclerotic plaques can be observed in vivo through imaging studies, such as CT-PET using 18F-fluorodeoxyglucose (Tarkin et al., 2014).

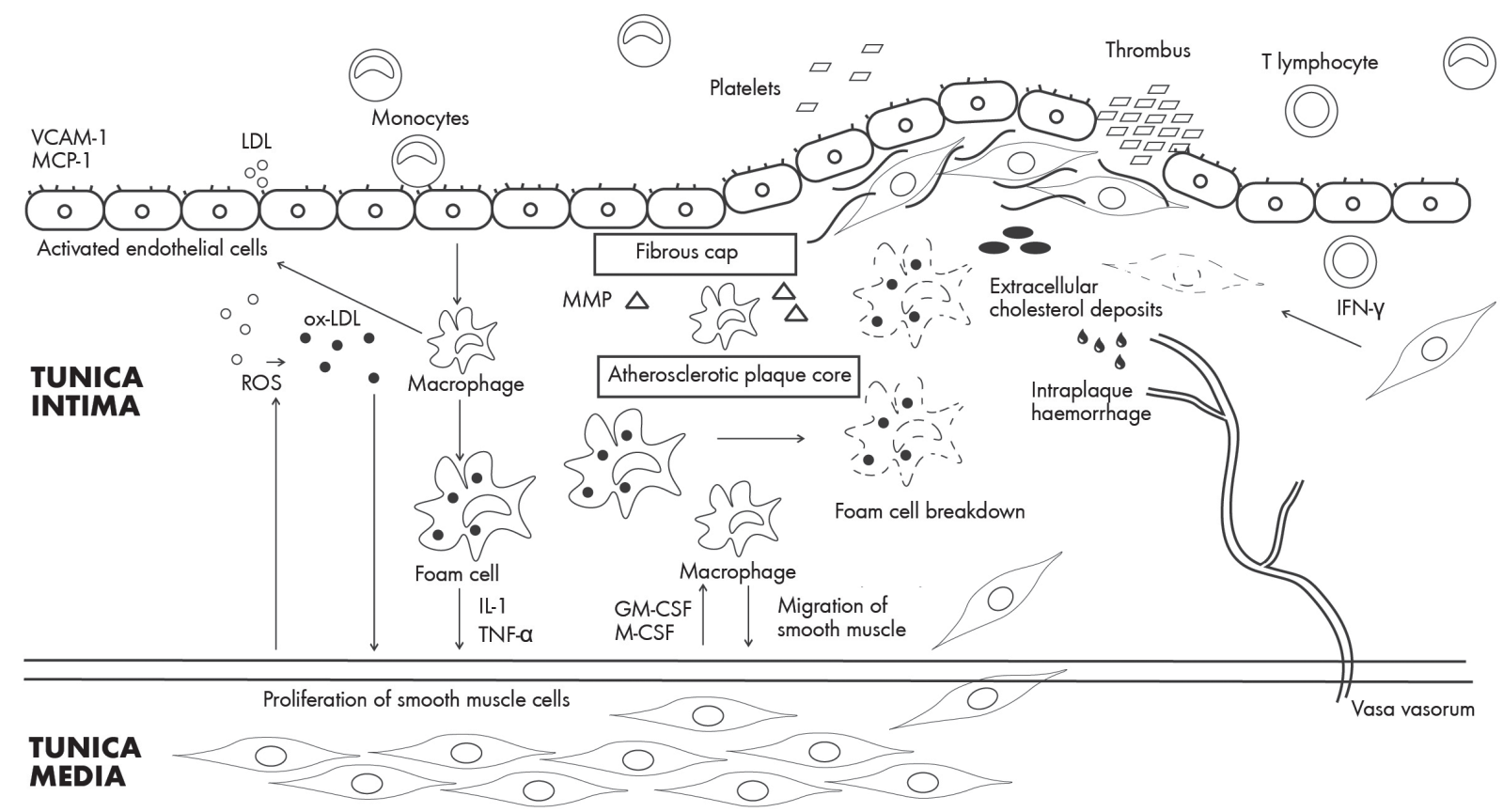

Figure 1 The role of inflammatory processes in atherosclerotic plaque development.

LDL - low-density lipoproteins; ox-LDL - oxidised forms of LDL; ROS - reactive oxygen species; VCAM-1 - vascular adhesion molecule type 1; MCP-1 - monocyte chemotactic protein type 1; IL-1 - interleukin 1; TNF- - - tumour necrosis factor a; GM-CSF - granulocyte and macrophage colony stimulating factor; M-CSF - macrophage colony stimulating factor; IFN- $\gamma$ - interferon $\gamma$; MMP - extracellular matrix metalloproteinase 


\section{Inflammatory process in the stroke}

Inflammation not only affects the development and destabilisation of atherosclerotic plaques, but is also a natural process induced by the primary brain injury caused by ischaemia or intracerebral haemorrhage (Mracsko and Veltkamp, 2014; Fu et al., 2015).

Cells of the nervous system deprived of oxygen suffer from metabolic disorders, such as ion imbalance and development of metabolic acidosis, mitochondrial dysfunction, activation of intracellular proteases and disintegration of the cell membrane structure (Anrather and Iadecola, 2016). Damaged nerve cells produce damage-associated molecular patterns (DAMPs), i.e. the so-called alarmins, which include heat shock proteins, adenosine $5^{\prime}$-triphosphate (ATP), purines, high mobility group binding protein 1 (HMGB1) and uric acid crystals. DAMPs induce non-specific immunity mechanisms that lead to secondary brain tissue damage (Shichita et al., 2012). In intracerebral haemorrhage, the immune system is additionally stimulated by extravasated blood cells and coagulation factors (Mracsko and Veltkamp, 2014). The process of secondary brain injury begins a few minutes after the stroke and may take up to several weeks. Initially, it is located mainly within the primary injury and in the surrounding tissues. The DAMPs activate the microglia in the brain parenchyma. Cytotoxic microglia produces interleukin $1 \beta$ (IL-1 $\beta$ ) and tumour necrosis factor $\alpha$ (TNF- $\alpha$ ) which stimulate astrocytes to produce chemokines and pro-inflammatory cytokines, and lead to activation of vascular endothelial cells increasing the inflow of inflammatory cells from the circuit. On the following days of the stroke, the microglia acquires phagocytic phenotype and secretes anti-inflammatory cytokines (e.g. IL-4, IL-10) and growth factors (e.g. TGF- $\beta$ ) to promote the repair of the blood-brain barrier and stimulate angiogenesis and scar formation (Machado-Pereira et al., 2017).

The astrocytes adjacent to neurons are the main line of defence against hypoxia. Elevated concentrations of extracellular potassium ions, associated with neuronal damage, cause glycolysis in astrocytes and the release of lactate and pyruvate supporting neuronal metabolism. Activated astrocytes also secrete compounds with antioxidant properties, such as glutathione or ascorbate, and growth factors with neuroprotective properties, such as nerve growth factor, brain-derived neurotrophic factor (BDNF), glial cell-derived neurotrophic factor (GDNF) and fibroblast growth factor 2 (FGF2). Although the initial astroglia response to nerve tissue damage is beneficial, extensive gliosis may lead to secondary brain damage since astrocytes are also a source of pro-inflammatory cytokines IL-1 $\beta$, IL- 6 , TNF- $\alpha$, IFN- $\gamma$, and chemokines, which in turn induce neuronal cell apoptosis, inhibit neurogenesis and stimulate recruitment of immune cells (Barreto et al., 2012; Schroeter, 1995).
At the same time, adhesion molecules appear on the surface of platelets and P-selectin endothelial cells as a result of a turbulent blood flow in a damaged vessel. The molecules bind to P-selectin glycoprotein ligand-1 (PSGL-1) on the surface of the leukocytes to induce adhesion to endothelial cells and migration to the brain parenchyma (Anrather and Iadecola, 2016). Platelets activated in vessels may form conglomerates, leading to re-closure of the vessel by thrombus or embolism. As a result, the patient's neurological deficit may be preserved or worsened. In addition, platelets which interact with T-regulatory lymphocytes facilitate further development of cerebral infarction in the process referred to as thrombo-inflammation (Stoll and Nieswandt, 2019). The complement system is also activated in the vessels and the blood-brain barrier is damaged. This process also involves matrix metalloproteinases and free radicals produced by neutrophils which are one of the first subpopulations of leukocytes activated after ischemic stroke. This allows an increased inflow of inflammatory cells ( $\gamma \delta \mathrm{T}$ lymphocytes, NK cells, monocytes and neutrophils) into the brain parenchyma (Majid, 2014). At the same time, cerebral oedema increases. In the case of increased mass effect, the patient may die due to brain structure displacement. The inflammatory processes are shown on Fig. 2.

Animal studies and the results of the brain post-mortem in patients who died of stroke suggest that the inflammatory response in the later stages of the stroke is not limited to the focus of the primary injury. It covers the entire brain. However, the exact mechanisms of the formation of the so-called global encephalitis are not entirely known. However, the emphasis is made on the relationship between the migrations of the activated microglia to the brain areas, distal from the infarct or haemorrhagic focus, in which secondary neurodegeneration occurred. The activation of micro glycol results from an increase in the levels of $18-\mathrm{kDa}$ translator protein. The increase can be measured in vivo with its ligand PK11195 using positron emission tomography. PK11195-PET in combination with the magnetic resonance diffusion tensor imaging additionally allows to trace its migration path. It seems that the results of the first human observational studies using these imaging techniques confirm the relationship between microglia activation and secondary neurodegeneration. However, due to the small number of study groups, further studies on a larger group of people are required (Thiel et al., 2010; Morris et al., 2018). Another hypothesis for the development of global encephalitis is the spread of inflammatory cells and inflammatory reaction mediators through cerebrospinal fluid (Shi et al., 2019; Mertens et al., 2018).

Transport of substances (e.g. cytokines, DAMPs) through the damaged blood-brain barrier also takes place from the brain parenchyma to the blood. Particularly high levels of pro-inflammatory cytokines in the blood are observed in the first day after the stroke. As in the 


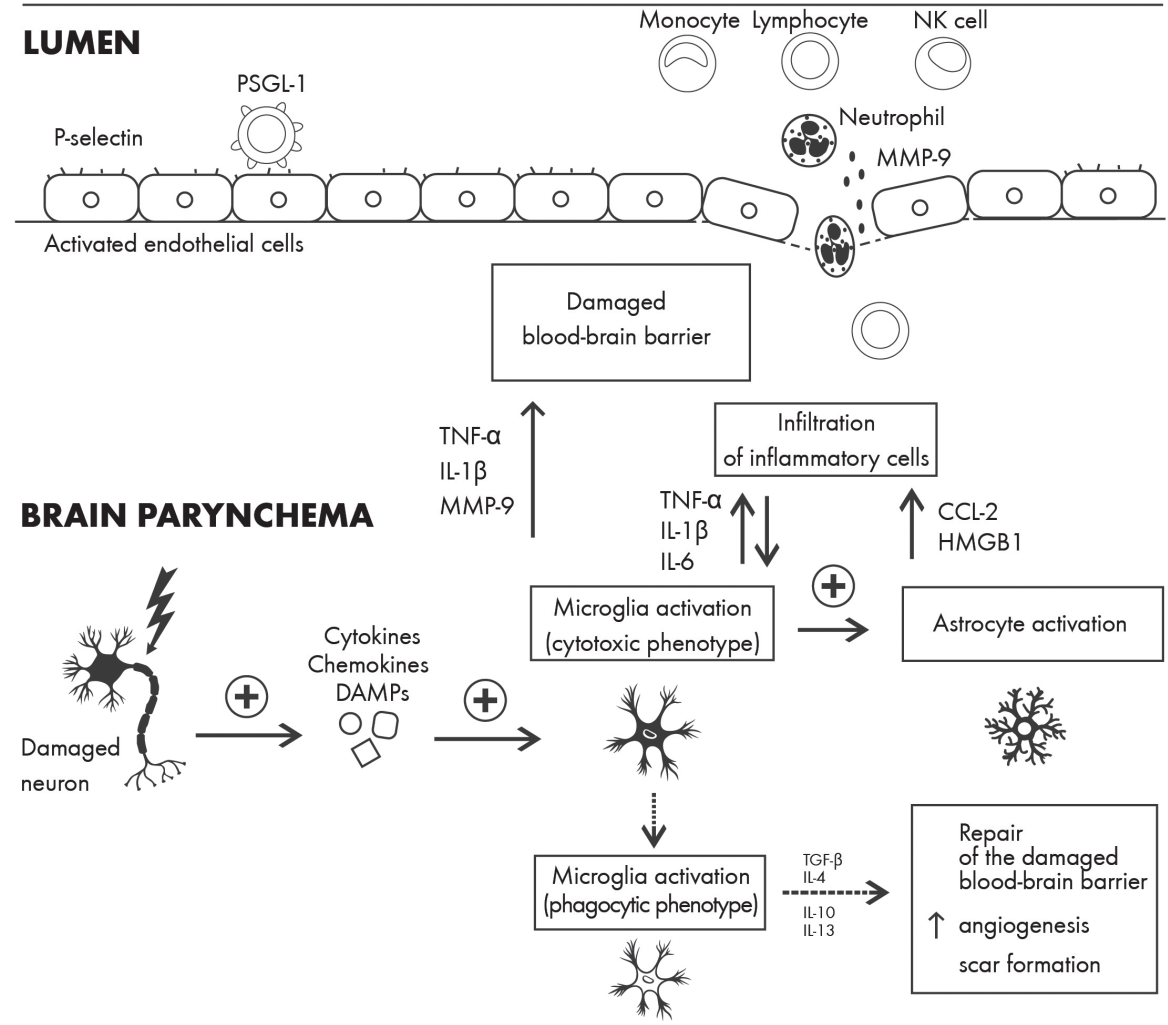

Figure 2 The role of inflammatory processes in the stroke.

PSGL-1 - P-selectin glycoprotein ligand-1; MMP-9 - extracellular matrix metalloproteinase 9; TNF- - - tumour necrosis factor $\alpha$; IL-1 $\beta$ - interleukin $1 \beta$; IL-6 - interleukin 6; HMGB1 - high mobility group 1 protein; CCL-2 - Chemokine (C-C motif) ligand 2, also known as monocyte chemotactic protein; TGF- $\beta$ - transforming growth factor $\beta$; IL-4 - interleukin 4; IL-10 - interleukin 10; IL-13 - interleukin 13; DAMPs - damage-associated molecular patterns, also called alarmins

case of IL-6, this may result in further adverse prognosis for the patient (Basic Kes et al., 2008; Jenny et al., 2019).

Patients with a higher absolute number of neutrophils in the blood also have a poorer prognosis of the alleviation of neurological syndrome and disability, higher mortality rates and increased risk of intracranial bleeding. Neutrophil Lymphocyte Ratio (NLR) indicator is an easily accessible tool to measure the severity of the inflammatory reaction. A higher NLR value also means greater disability and a higher risk of intracranial bleeding (Maestrini et al., 2015; Zhang et al., 2017).

Some studies have shown that in thrombolytic patients, elevated CRP on admission resulted in poorer prognosis within 3 months of ischaemic stroke (Montaner et al., 2006; Tiainen et al., 2013). Other studies have shown that elevated CRP levels, measured within 24 hours of the stroke, do not appear to be an independent prognostic factor. They are rather associated with other factors that worsen the patient's prognosis, such as diabetes, congestive heart failure and previous infections (Karliński et al., 2014).

However, shortly after the stroke, peripheral immune system cells are rapidly inhibited: the number of B lymphocytes, T lymphocytes and NK cells decreases, the number of regulatory $\mathrm{T}$ cells in blood serum increases,
IFN- $\gamma$ concentration decreases, and the synthesis of interleukin 5 (IL-5) and interleukin 10 (IL-10) increases. This process is most likely the result of the activation of the sympathetic nervous system by oxidative stress (Meisel and Meisel, 2011; Członkowska et al., 1979). Immune system suppression is the cause of infectious complications in stroke patients (Koennecke et al., 2011).

\section{Drugs with anti-inflammatory effects}

\section{Prevention of atherosclerosis and its complications}

Studies conducted so far prove that the treatment of inflammation can be a promising strategy to reduce the risk of developing atherosclerosis and its complications.

The use of anti-inflammatory therapy with canakinumab (monoclonal antibody neutralising interleukin $1 \beta$ ) in patients with chronic inflammatory process (highly sensitive CRP $>2 \mathrm{mg} / \mathrm{l}$ ), without clear infectious or cancerous background, after acute myocardial infarction (CANTOS - Canakinumab Anti-inflammatory Thrombosis Outcomes Study) significantly reduced the risk of serious cardiovascular episodes compared to placebo. By its effect on IL-1 $\beta$, which is the main trigger of inflammatory 
reaction, the drug reduced the level of inflammatory parameters, i.e. CRP, fibrinogen and IL-6. It is worth noting that canakinumab does not reduce lipid concentrations. This means that the reduction of cardiovascular risk is the effect of suppressing inflammatory reactions only in this case (Ridker et al., 2017).

Another substance showing anti-inflammatory effects is colchicine, used so far to treat gout, Beḩet's disease and familial Mediterranean fever. Colchicine inhibits the activation of cryopyrin (LRR and PYD domains-containing proteins 3 , NLRP3), reducing the activity of IL-1 $\beta$, IL- 6 and other pro-inflammatory cytokines. It also binds to tubulin to inhibit the formation of microtubules, limiting inflammatory cell division and migration (Leung et al., 2015).

The Colchicine Cardiovascular Outcomes Trial (COLCOT) assessed the efficacy of low-dose colchicine ( $0.5 \mathrm{mg} /$ day) in preventing serious cardiovascular incidents after myocardial infarction. Death from cardiovascular causes, cardiac arrest, myocardial infarction, stroke and hospitalisation for coronary revascularisation served as the main clinical endpoints. The use of colchicine resulted in overall reduction in the relative risk of the above events and significant reduction in the relative risk of strokes (Tardif et al., 2019).

The CONVINCE study (Colchicine for prevention of Vascular Inflammation in Non-Cardio Embolic Stroke) is currently underway. It uses a low dose of colchicine $(0.5 \mathrm{mg} /$ day) in secondary prevention of vascular events (ischaemic stroke, myocardial infarction, unstable angina, cardiac arrest or death as a result of the above mentioned diseases). The study plans to include 3,154 patients over 40 years of age with a transient high-risk ischaemic episode or ischaemic stroke due to arterial stenosis or an unclear mechanism (cryptogenic stroke). The end of the study, after the 3-year observation of patients, is scheduled for 2023 (Kelly et al., 2020).

\section{Stroke}

Several studies have also been conducted using immunomodulating drugs in the acute stage of ischaemic stroke in order to reduce the development of stroke focus.

In particular, enlimomab, anti-cellular adhesion molecule antibody (ICAM-1) was used. It reduced leukocyte adhesion and cerebral infarction volume in rodent models. However, it did not produce the expected results in a clinical trial involving a total of 625 patients with ischaemic stroke. In the group of people who took the drug, higher mortality and higher mRS after 90 days after the stroke were observed. The complete resolution of neurological symptoms was less frequent and adverse events occurred more frequently, mainly infections and fever (Sherman et al., 2001).

The ASTIN study (Acute Stroke Therapy by Inhibition of Neutrophils) assessed the effect of the neutrophil inhibitor (UK-279, 276) in patients with ischaemic stroke.
It included 966 patients. The study was discontinued due to lack of therapeutic effects after drug administration (Krams et al., 2003).

Although studies published at the beginning of the 21st century did not produce positive results, after a few years, research on the use of new molecules was resumed. In 2014, the results of the study with fingolimod, a non-selective modulator of sphingosine-1-phosphate receptor (S1P) were published (Fu et al., 2014). Fingolimod prevents lymphocytes from escaping from lymph nodes. Experimental studies have shown that it reduces lymphocyte infiltration into the brain parenchyma and inhibits local activation of microglia and macrophages. This reduces oedema around the stroke core and the final size of the ischaemic focus. A pilot study conducted in 2014 assessed the effects of fingolimod administration in patients with ischaemic stroke. The study included $22 \mathrm{pa-}$ tients who were admitted to hospital between 4.5 hours and 72 hours after the stroke. Patients who received the drug more often showed the improvement of neurological condition. Laboratory tests showed a lower number of circulating leukocytes in the blood compared to the control group. No serious complications were observed after fingolimod administration. The drug requires further testing on a larger group of patients.

The reduction of the influx of lymphocytes into the parenchyma may have positive effects, not only in ischemic stroke, but probably also in the treatment of intracerebral haemorrhages. Studies on mice have shown reduced oedema and neurological deficit as well as increased survival in rodents who were administered siponimod (Bobinger et al., 2019). Siponimod, a drug with code BAF312, is a selective modulator of two of the five S1P receptors, i.e. S1PR1 and S1PR5. It shows similar effects to fingolimod but with a higher selectivity with action focused on white blood cells, which makes it more safe to use while similar benefit profile. Efficacy, Safety, and Tolerability of BAF312 Compared to Placebo in Patients with Intracerebral Haemorrhage, i.e. the study with siponimod administration in patients with spontaneous supratentorial intracerebral haemorrhage, is currently underway. Approximately 60 patients aged 18-85 years are planned to be included. The drug will be administered for about 14 days, initially intravenously and then orally. After this time, brain oedema accompanying the haemorrhage will serve as the primary endpoint and the siponimod concentration in the blood will serve as the secondary endpoint. The study is scheduled to be completed in November 2021 (www.clinicaltrials. gov/ct2/show/NCT03338998).

Natalizumab is another interesting drug. It is a monoclonal antibody directed against the a4 subunit of the adhesion molecule (very late antigen-4, VLA-4) and causes reduced leukocyte migration through the vascular endothelium. The ACTION study has shown that although natalizumab did not limit the volume of ischaemic focus 
and did not affect NIHSS, it improved cognitive functions and reduced disability, which was assessed 90 days after the disease. This study was conducted on 161 patients aged 18-85 years (Elkins et al., 2017). The use of natalizumab in the treatment of acute ischaemic stroke requires further research.

Another drug inhibiting the activation of inflammatory cells and their inflow to the central nervous system is fisetin (bioactive flavonoid). In a clinical study on the use of fisetin in combination with tissue plasminogen activator (rt-PA) in the treatment of acute ischaemic stroke, fisetin significantly improved patient outcomes. As many as $42.5 \%$ of patients scored from 0 to 10 NIHSS points on the 7th day after combined treatment (fisetin $+\mathrm{rtPA}$ ) within 3 to 5 hours after the disease. In the group treated with rtPA, $32.3 \%$ of patients scored similarly. In the group treated with fisetin with rtPA, a lower percentage of patients who scored more than 20 NIHSS points was reported (19.4\% as compared to $39.7 \%)$. The beneficial effect of fisetin was probably due to the reduction of metalloproteinases 2 and 9 (MMP-2, MMP-9) and CRP levels in serum, as evidenced by strong linear correlations between the levels of these markers in serum and NIHSS results in all patients included in the study (Wang et al., 2019).

Thanks to its anti-inflammatory properties, the human recombinant interleukin-1 receptor antagonist (IL1ra) may also prove to be a good therapeutic agent for stroke treatment. Studies on rodents with induced middle cerebral artery occlusion have shown that both IL1ra overexpression and administration of IL1ra intravenously or to peripheral vessels significantly reduced the infarct volume, oedema, glial activation and brain infiltration with peripheral blood cells. Animals treated with IL1ra also achieved better behavioural results (Pradillo et al., 2012). In humans, the IL-1 receptor agonist is encoded by a polymorphic IL-IRN gene located on chromosome 2. Recent studies have shown that the *2 IL-1RN allele homozygous patients had better neurological and functional improvement results within 7 days to 1 year of the ischemic stroke compared to patients with other genotypes. This was most likely due to the increased synthesis of IL-1 receptor antagonist (IL1ra) in monocytes and IL1RN*2/IL1RN*2 homozygote microglia, which may inhibit the inflammatory reaction and consequently reduce secondary brain injury. Given the genetic background, at least some patients could potentially benefit from the use of a human recombinant IL-1 receptor antagonist in acute ischaemic stroke (Gromadzka et al., 2007).

\section{Prevention of immunosuppression}

Due to the high number of infections (especially respiratory and urinary tract infections) in patients with stroke, attempts were made to use antibiotics, $\beta$-blockers (Barer et al., 1988; Dziedzic et al., 2007, Chamorro et al., 2005) and immunoglobulins (IVIG) in the prevention of these infections. A study on a group of 71 patients has shown that IVIG administration within 5 days of the ischaemic stroke reduced infection-related mortality, in particular due to pneumonia. The greatest benefit was observed in patients with lower levels of immunoglobulin in the blood (Palasik et al., 1999). The randomised controlled clinical trial PRECIOUS (The PREvention of Complications to Improve the OUtcome in elderly patients with acute Stroke) is also currently underway. Its aim is to assess the efficacy of a combination of ceftriaxone, paracetamol, and metoclopramide in preventing infections, aspiration, and fever after ischaemic or haemorrhagic stroke. These drugs should be used up to 24 hours and maintained for 96 hours after the onset of the disease according to the test protocol. It is planned to include 3,800 patients aged over 66 years with a NIHSS score of 6 or more and a prestroke disability of less than 4 in mRS (modified Rankin Scale). The date of completion of the PRECIOUS study was scheduled for 31 May 2020 (Reinink et al., 2018).

\section{Conclusions}

Successive experimental and clinical studies show the important role of inflammatory cells and the molecules they produce in the development and course of strokes. However, it is still uncertain how external modulation of the inflammatory reaction in the stroke affects the final results of the treatment. Although anti-inflammatory drugs are undoubtedly a tempting option in the treatment of acute and subacute phase of the ischemic stroke, there is a risk of exacerbation of immunosuppression, naturally occurring in the stroke, and related infectious complications.

\section{Wstęp}

Proces zapalny jest wrodzonym, fizjologicznym mechanizmem obronnym organizmu w reakcji na czynniki uszkadzające jego tkanki. W ostrym zapaleniu dzięki zmianom w przepływie krwi, wzroście przepuszczalności naczyń

oraz aktywacji i migracji krwinek białych do uszkodzonej tkanki dochodzi do likwidacji uszkadzających organizm czynników, usunięcia martwych tkanek organizmu oraz przyspieszenia procesu gojenia. Jednak, jeśli proces zapalny trwa przewlekle, nadmierna stymulacja odpowiedzi immunologicznej może doprowadzić do powstania 
reakcji nadwrażliwości czy rozwoju reakcji autoimmunologicznych (Całkosiński i wsp., 2009). Liczne badania doświadczalne i kliniczne zwracają uwagę na rolę zapalenia i reakcji immunologicznych zarówno w patogenezie miażdżycowego uszkodzenia naczyń, jak i rozwoju ogniska udarowego. Samo uszkodzenie mózgu powoduje również zaburzenia immunologiczne prowadzące do powikłań poudarowych. Modulacja reakcji zapalnej jest obecnie uważana za obiecującą strategię w profilaktyce i leczeniu udaru. Zagadnienia te i toczące się obecnie badania kliniczne zostaną omówione w niniejszej pracy.

\section{Proces zapalny w miażdżycy}

Miażdżycę jako chorobę tętnic średniego i dużego kalibru wiązano początkowo głównie $\mathrm{z}$ dyslipidemią i odkładaniem się złogów cholesterolu w błonie wewnętrznej tych naczyń. Dopiero na początku lat 70. XX wieku Russel Ross wysunął hipotezę, że miażdżyca jest procesem zapalnym będącym odpowiedzią ściany naczynia na uszkodzenie (Ross, 1999). Aktualnie dostępne dane wykazują, że niezależnie od tego, który proces był pierwotnym czynnikiem wyzwalającym, to stan zapalny i dyslipidemia koegzystują ze sobą od wczesnych etapów rozwoju miażdżycy aż do czasu pęknięcia lub erozji blaszek miażdżycowych i związanych z tym powikłań sercowo-naczyniowych. Hipercholesterolemia inicjuje proces zapalny, ale skorygowanie zaburzeń lipidowych nie wystarcza, aby zahamować rozwój miażdżycy. Ponadto, aż około $50 \%$ pacjentów z miażdżycą nie ma wyjściowo hipercholesterolemii. Zapalnie może być zatem niezależnym od lipidów czynnikiem inicjującym proces powstawania blaszek miażdżycowych. Wykazano, że przewlekłe ogólnoustrojowe zapalenie o niskim stopniu nasilenia, laboratoryjnie mierzone za pomocą stężenia białka C-reaktywnego ( $C$ reactive protein, $\mathrm{CRP}$ ), wiąże się ze zwiększonym ryzykiem miażdżycy (Manduteanu i Simionescu, 2012).

Lipoproteiny o małej gęstości (low-density lipoprotein, LDL) stanowią główną frakcję cholesterolu transportowaną ze światła naczyń do tkanek. W miejscach podatnych na rozwój miażdżycy, takich jak rozwidlenia tętnic i miejsca odejścia tętnic mniejszego kalibru, może dochodzić do gromadzenia LDL w przestrzeni podśródbłonkowej w błonie wewnętrznej, zwłaszcza u pacjentów z podwyższonym poziomem LDL i obniżonym poziomem lipoprotein o wysokiej gęstości (high-density lipoprotein, HDL) w surowicy. Po opuszczeniu światła naczynia cząsteczki LDL ulegają różnym procesom modyfikującym, wśród których dominuje utlenianie (Ercan i wsp., 2014). Utlenione cząsteczki LDL (oxy-LDL) przez swój wpływ na komórki śródbłonka hamują aktywność enzymu syntetyzującego tlenek azotu (nitric oxide synthase 3, NOS-3), stymulują produkcję endoteliny 1 i zwiększają jej właściwości wazokonstrykcyjne, aktywują lektynopodobne receptory błonowe dla utlenionego LDL (lectin-like oxidized low-density lipoprotein, LOX1), zwiększając aktywność enzymu konwertującego angiotensynę $\mathrm{i}$ jego receptora AT1 oraz bezpośrednio stymulują komórki mięśni gładkich do proliferacji, zwiększając tym samym objętość blaszki miażdżycowej (Pasierski i Andziak, 2004; Kranzhofer i wsp., 1999).

Komórki śródbłonka wraz z kolagenową błoną podstawną stanowią barierę między światłem naczynia a pozostałymi warstwami jego ściany. Przez wydzielane substancje śródbłonek kontroluje przepuszczalność ściany naczynia dla komórek krwi, moduluje napięcie mięśni gładkich ściany naczynia, wpływa na procesy krzepnięcia i fibrynolizy, a także uczestniczy w regulacji procesów zapalnych. Do rozwoju reakcji zapalnej, poprzedzonej aktywacją komórek śródbłonka, dochodzi nie tylko w przebiegu hiperlipidemii, ale także w przebiegu innych chorób, takich jak nadciśnienie tętnicze, zakażenia (zwłaszcza o etiologii Chlamydophila pneumoniae), cukrzyca czy otyłość (Libby i wsp., 2002; Kranzhofer i wsp., 1999, Yudkin i wsp., 1999).

W aktywowanych komórkach śródbłonka dochodzi do uwolnienia jądrowego czynnika transkrypcji kappa B (nuclear factor kappa B, NFkB). Zostaje przez to zwiększona ekspresja białek adhezyjnych, takich jak E-selektyny, naczyniowa cząsteczka przylegania komórkowego typu 1 (vascular cell adhesion molecule 1, VCAM-1) oraz białko chemotaktyczne monocytów typu 1 (monocyte chemotactic protein 1, MCP-1) umożliwiających migrację komórek zapalnych (głównie monocytów i limfocytów) do wnętrza ściany naczynia. Monocyty pod wpływem czynników stymulujących wzrost kolonii makrofagów wytwarzanych przez komórki śródbłonka i komórki mięśni gładkich - takich jak M-CSF (macrophage colony stimulating factor) oraz GM-CSF (granulocyte-macrophage colony stimulating factor) - ulegają przekształceniu w makrofagi. Makrofagi wykazują wysoką ekspresję receptorów zmiatających i pochłaniając oxy-LDL, przybierają postać komórek piankowatych, niwelując ich szkodliwy wpływ na komórki śródbłonka i komórki mięśni gładkich. Z czasem jednak w przeładowanych lipidami komórkach piankowatych dochodzi do wytrącania się wolnych kryształów cholesterolu, które doprowadzają do rozpadu komórki i akumulacji złogów cholesterolu pozakomórkowo - powstaje rdzeń tłuszczowy blaszki miażdżycowej. Poza tym makrofagi stymulują ekspresję cząsteczek adhezyjnych na komórkach śródbłonka, nasilając napływ do ściany naczynia innych komórek zapalnych oraz pobudzają migrację komórek mięśni gładkich z błony środkowej do błony wewnętrznej (Banach i wsp., 2004). Komórki mięśni gładkich syntezują kolagen oraz proteoglikany, tworząc tzw. czapeczkę włóknistą, która stabilizuje blaszkę miażdżycową.

Należy pamiętać, że aktywowane komórki śródbłonka oddziałują nie tylko na krwinki białe, ale także na płytki krwi, sprzyjając ich agregacji, oraz, przez ekspresję 
czynnika tkankowego, inicjują zewnątrzpochodny szlak krzepnięcia krwi. Trombina jest nie tylko istotnym elementem kaskady krzepnięcia, ale także silnym czynnikiem prozapalnym. Stymuluje rekrutacje monocytów przez nasilenie ekspresji białka MCP-1, aktywuje komórki mięśni gładkich przez receptor proteaz typu 1 (PAR-1) oraz - obok adenozyno-5'-difosforanu (ADP) jest najsilniejszym aktywatorem płytek powodującym ich degranulację (Jarząbek i wsp., 2015; d'Audigier i wsp., 2015). Skrzepliny najczęściej tworzą się na powierzchni blaszek, które uległy pęknięciu, lub w mniejszym stopniu na powierzchni blaszek, które uległy erozji (odsłonięta została błona podstawna wskutek uszkodzenia komórek śródbłonka). W niestabilnych blaszkach miażdżycowych często obserwowany jest też proces neowaskularyzacji i krwotoki do wnętrza blaszek. Jednym z głównych czynników destabilizujących blaszki są wspomniane wcześniej komórki zapalne - limfocyty T i makrofagi. Limfocyty $\mathrm{T}$ przez wydzielany interferon $\gamma$ (IFN- $\gamma$ ) hamują syntezę kolagenu przez komórki mięśni gładkich oraz stymulują ich apoptozę. Zaś makrofagi, przez wytwarzane metaloproteinazy (kolagenazę, żelatynazę, stromolizynę), niszczą czapeczkę włóknistą blaszki miażdżycowej (Amento i wsp., 1991). Opisane procesy przedstawiono na rycinie 1.

Obecność reakcji zapalnej w blaszkach miażdżycowych u ludzi można zaobserwować in vivo dzięki badaniom obrazowym, takim jak badanie CT-PET z użyciem 18F-fluorodeoksyglukozy (Tarkin i wsp., 2014).

\section{Proces zapalny w udarze}

Zapalenie nie tylko wpływa na rozwój i destabilizację blaszek miażdżycowych, ale jest także naturalnym procesem indukowanym przez pierwotne uszkodzenie mózgu w wyniku niedokrwienia czy krwotoku śródmózgowego (Mracsko i Veltkamp, 2014; Fu i wsp., 2015).

W niedotlenionych komórkach układu nerwowego dochodzi do zaburzeń metabolicznych, takich jak zaburzenia gospodarki jonowej i rozwój kwasicy metabolicznej, dysfunkcja mitochondriów, aktywacja wewnątrzkomórkowych proteaz oraz dezintegracja elementów błony komórkowej (Anrather i Iadecola, 2016). Z uszkodzonych komórek nerwowych wydzielane są struktury molekularne związane z zagrożeniem (damage-associated molecular patterns, DAMPs) tzw. alarminy, do których należą m.in. białka szoku cieplnego, adenozyno-5'-trifosforan (ATP), puryny, białko grupy 1 o wysokiej ruchliwości (high mobility group binding protein, HMGB1) oraz kryształy kwasu moczowego. DAMPs indukują mechanizmy odporności nieswoistej, które doprowadzają do wtórnego uszkodzenia tkanek mózgu (Shichita i wsp., 2012). W krwotoku śródmózgowym dodatkowymi czynnikami stymulującymi układ immunologiczny są wynaczynione elementy morfotyczne krwi oraz czynniki krzepnięcia (Mracsko i Veltkamp, 2014). Proces wtórnego uszkodzenia mózgu rozpoczyna się już po kilku minutach od wystąpienia udaru i może trwać nawet do kilku tygodni, lokalizując się początkowo głównie w obrębie ogniska

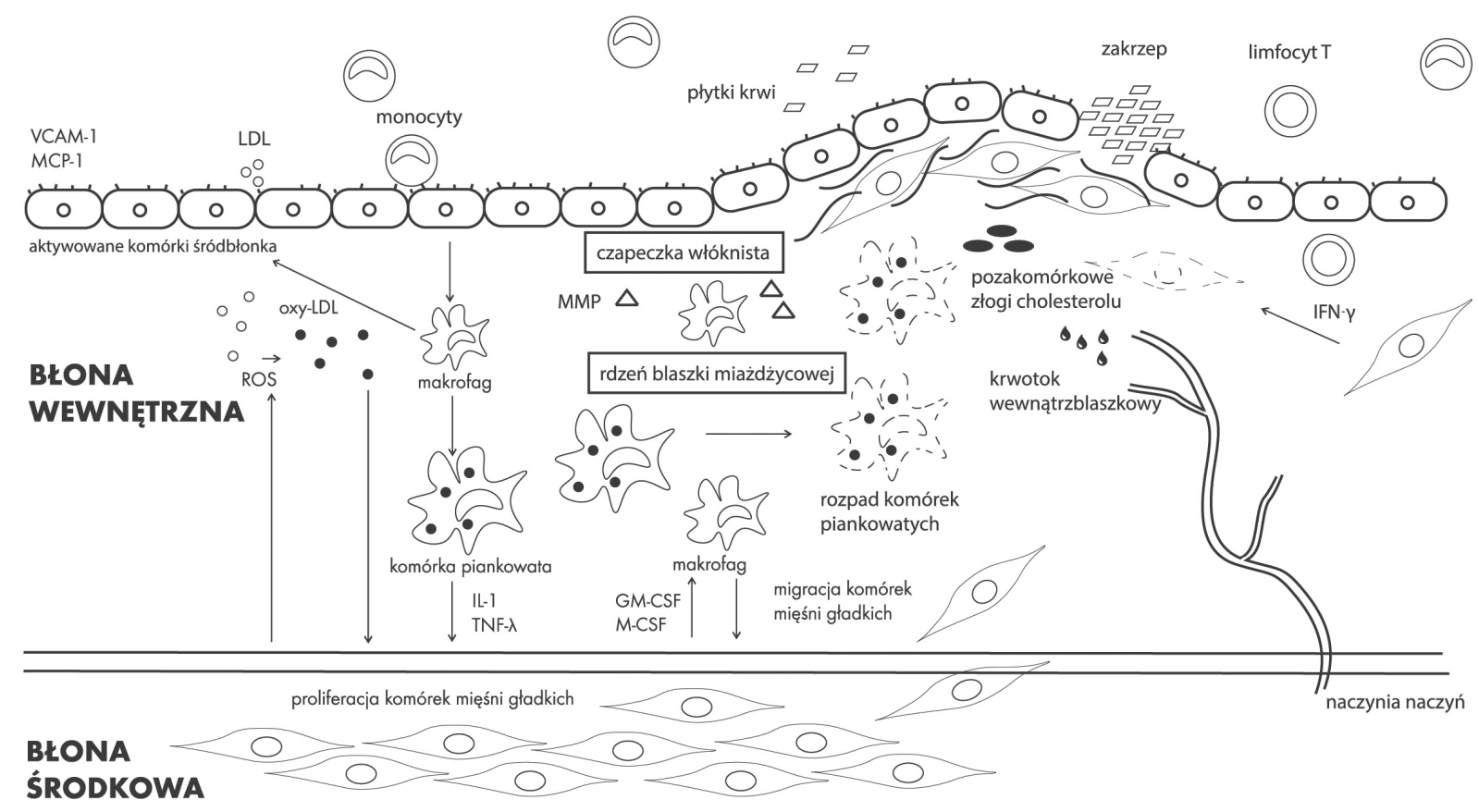

Rycina 1 Rola procesów zapalnych w rozwoju blaszki miażdżycowej.

LDL - lipoproteiny o małej gęstości; oxy-LDL - utlenione formy LDL; ROS - wolne rodniki tlenu; VCAM-1 - naczyniowa cząsteczka przylegania komórkowego typu 1; MCP-1 - białko chemotaktyczne monocytów typu 1; IL-1 - interleukina 1; TNF-a - czynnik martwicy nowotworów a; GMCSF - czynnik stymulujący tworzenie kolonii granulocytów i makrofagów; M-CSF - czynnik stymulujący tworzenie kolonii makrofagów; IFN- $\gamma$ - interferon ү; MMP - metaloproteinaza macierzy zewnątrzkomórkowej 
pierwotnego uszkodzenia i w otaczających tkankach. W miąższu mózgu DAMPs aktywują mikroglej. Mikroglej o fenotypie cytotoksycznym wydziela interleukinę $1 \beta$ (IL-1 $\beta$ ) oraz czynnik martwicy nowotworów $\alpha$ (TNF- $\alpha$ ), które pobudzają astrocyty do produkcji chemokin i cytokin prozapalnych oraz doprowadzają do aktywacji komórek śródbłonka naczyń, co powoduje zwiększenie napływu komórek zapalnych z obwodu. W kolejnych dobach udaru mikroglej zmienia fenotyp na fagocytarny i przez wydzielanie cytokin przeciwzapalnych (m.in. IL-4, IL-10) oraz czynników wzrostowych (m.in. TGF- $\beta$ ) sprzyja naprawie bariery krew-mózg i stymuluje angiogenezę oraz tworzenie się blizny (Machado-Pereira i wsp., 2017).

Główną linię obrony neuronów przed niedotlenieniem stanowią sąsiadujące z nimi astrocyty. Podwyższone stężenie pozakomórkowych jonów potasu, związane z uszkodzeniem neuronów, powoduje glikolizę w astrocytach i uwalnianie z nich mleczanu i pirogronianu, które wspierają metabolizm neuronów. Aktywowane astrocyty wydzielają także związki o właściwościach antyoksydacyjnych, takie jak glutation czy askorbinian, oraz czynniki wzrostowe o właściwościach neuroprotekcyjnych, takie jak np. nerwowy czynnik wzrostu (nerve growth factor, NGF), czynnik neurotroficzny pochodzenia mózgowego (brain-derived neurotrophic factor, BDNF), czynnik neurotroficzny pochodzenia glejowego (glial cell-derived neurotrophic factor, GDNF) oraz czynnik wzrostu fibroblastów 2 (fibroblast growth factor 2 , FGF2). Mimo iż początkowa odpowiedź astrogleju na uszkodzenie tkanki nerwowej jest korzystna, rozległa glejoza może przyczyniać się do wtórnego uszkodzenia mózgu, gdyż astrocyty są również źródłem cytokin prozapalnych IL-1 $\beta$, IL-6, TNF- $\alpha$, IFN- $\gamma$ oraz chemokin, które z kolei indukują apoptozę komórek neuronalnych, hamują neurogenezę oraz stymulują rekrutacje komórek odpornościowych (Barreto i wsp., 2012; Schroeter, 1995).

W tym samym czasie w uszkodzonym naczyniu turbulentny przepływ krwi powoduje pojawienie się na powierzchni płytek krwi i komórek śródbłonka P-selektyn, cząsteczek adhezyjnych, które wiążą się z glikoproteinowym ligandem 1 selektyny P (P-selectin glycoprotein ligand-1, PSGL-1) na powierzchni leukocytów, umożliwiając ich adhezję do komórek śródbłonka, a następnie migrację do miąższu mózgu (Anrather i Iadecola, 2016). Aktywowane w naczyniach płytki krwi mogą tworzyć konglomeraty, doprowadzając do ponownego zamknięcia naczynia przez zakrzep lub zator, a w konsekwencji utrwalenia lub pogorszenia deficytu neurologicznego pacjenta. Dodatkowo, płytki krwi oddziałując z limfocytami T regulatorowymi, ułatwiają dalszy rozwój zawału w procesie określanym jako zapalenie zakrzepowe (Stoll i Nieswandt, 2019). W naczyniach aktywowany zostaje również układ dopełniacza i dochodzi do uszkodzenia bariery krew-mózg. W procesie tym biorą również udział metaloproteinazy macierzy i wolne rodniki produkowane przez neutrofile, które są jedną z pierwszych subpopulacji leukocytów uaktywniających się po wystąpieniu udaru niedokrwiennego mózgu. Umożliwia to zwiększony napływ komórek zapalnych (limfocytów $\mathrm{T} \gamma \delta$, komórek NK, monocytów i neutrofili) do miąższu mózgu (Majid, 2014). Jednocześnie zwiększa się obrzęk mózgu, a w przypadku wystąpienia nasilonego efektu masy może dojść do zgonu pacjenta w mechanizmie przemieszczenia struktur mózgu. Opisane procesy zapalne przedstawiono na rycynie 2.

Jak sugerują badania na zwierzętach i wyniki sekcji mózgów pacjentów zmarłych z powodu udaru, odpowiedź zapalna w późniejszych fazach udaru nie ogranicza się wyłącznie do ogniska pierwotnego uszkodzenia, ale obejmuje cały mózg, choć dokładne mechanizmy powstania tak zwanego globalnego zapalenia mózgu nie są do końca znane. Podkreśla się jednak związek migracji aktywowanego mikrogleju w obszary mózgu położone dystalnie od ogniska zawałowego czy krwotocznego, w których doszło do wtórnej neurodegeneracji. Aktywacja mikrogleju jest związana z podwyższeniem poziomów białka translokatora $18 \mathrm{kDa}$, co można zmierzyć in vivo za pomocą jego ligandu PK11195 przy wykorzystaniu pozytronowej tomografii emisyjnej. Badanie PK11195-PET w połączeniu z obrazowaniem tensora dyfuzji rezonansu magnetycznego pozwala dodatkowo prześledzić ścieżkę jego migracji. Wyniki pierwszych badań obserwacyjnych u ludzi z wykorzystaniem powyższych technik obrazowych wydają się potwierdzać związek aktywacji mikrogleju i wtórnej neurodegeneracji, jednak ze względu na niewielką liczebność badanych grup, niezbędne jest prowadzenie dalszych badań na większej grupie osób (Thiel i wsp., 2010; Morris i wsp., 2018). Inną hipotezą rozwoju globalnego zapalenia mózgu jest rozprzestrzenianie się komórek zapalnych i mediatorów reakcji zapalnej za pośrednictwem płynu mózgowo-rdzeniowego (Shi wsp., 2019; Mertens i wsp., 2018).

Transport substancji (np. cytokin, DAMPs) przez uszkodzoną barierę krew-mózg odbywa się także z miąższu mózgu do krwi. Szczególnie wysoki poziom cytokin prozapalnych we krwi obserwuje się w pierwszej dobie po udarze i może on korelować jak w przypadku IL-6 $\mathrm{z}$ dalszymi niekorzystnymi rokowaniami pacjenta (Basic Kes i wsp., 2008; Jenny i wsp., 2019).

Również pacjenci z wyższą bezwzględną liczbą neutrofili we krwi mają gorsze rokowanie co do ustępowania zespołu neurologicznego i stopnia niepełnosprawności, wyższą śmiertelność oraz zwiększone ryzyko krwawienia wewnątrzczaszkowego. Wskaźnik NLR będący ilorazem liczby neutrofili do limfocytów jest łatwo dostępnym narzędziem mierzącym nasilenie reakcji zapalnej. Wyższa wartość NLR wiąże się również z większą niepełnosprawnością oraz większym ryzykiem krwawienia wewnątrzczaszkowego (Maestrini i wsp., 2015; Zhang i wsp., 2017). 


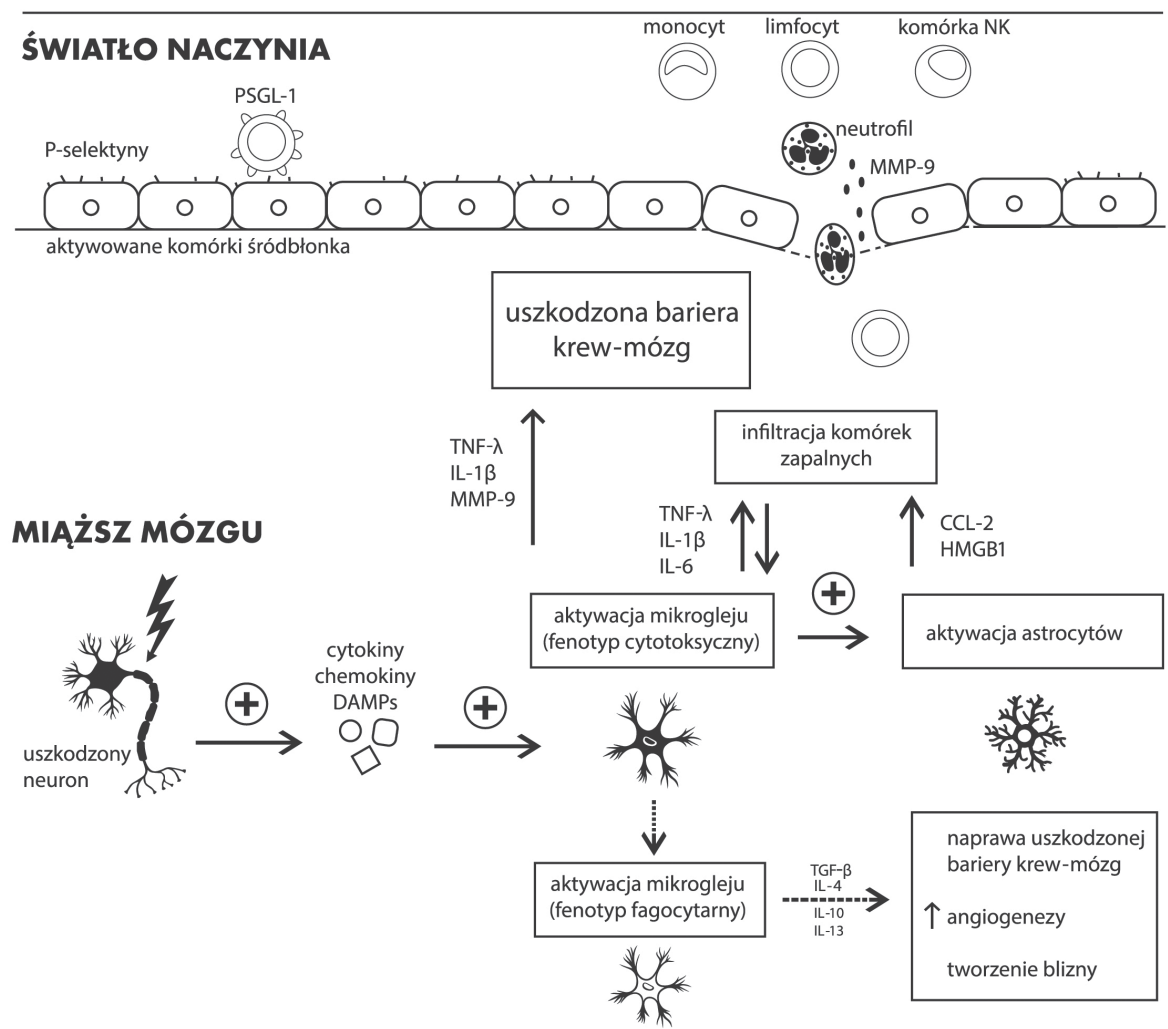

Rycina 2 Rola procesów zapalnych w udarze mózgu.

PSGL-1 - glikoproteinowy ligand 1 selektyny P; MMP-9 - metaloproteinaza macierzy zewnątrzkomórkowej 9; TNF-a - czynnik martwicy nowotworów $\alpha$; IL-1 $\beta$ - interleukina $1 \beta$; IL-6 - interleukina 6; HMGB1 - białko grupy 1 o wysokiej ruchliwości; CCL-2 - ligand 2 chemokiny CC zwany także białkiem chemotaktycznym monocytów; TGF- $\beta$ - transformujący czynnik wzrostu $\beta$; IL-4 - interleukina 4; IL-10 - interleukina 10; IL-13 - interleukina 13; DAMPs - struktury molekularne związane z zagrożeniem tzw. alarminy

W przypadku pacjentów leczonych trombolitycznie niektóre badania wykazały, że podwyższone stężenie CRP przy przyjęciu wiązało się z gorszym rokowaniem w ciągu 3 miesięcy od wystąpienia udaru niedokrwiennego mózgu (Montaner i wsp., 2006; Tiainen i wsp., 2013). Z kolei inne badania wykazywały, że podwyższone stężenie CRP, mierzone w ciągu 24 godzin od wystąpienia udaru, nie wydaje się niezależnym czynnikiem prognostycznym, lecz jest związane z innymi czynnikami pogorszającymi rokowanie pacjenta, takimi jak cukrzyca, zastoinowa niewydolność serca czy wcześniejsze infekcje (Karliński i wsp., 2014).

Wkrótce po wystąpieniu udaru dochodzi jednak do gwałtownego zahamowania obwodowych komórek układu immunologicznego: obniża się liczba limfocytów B, limfocytów T i komórek NK oraz wzrasta liczba limfocytów T regulatorowych w surowicy krwi, obniża się stężenie IFN- $\gamma$, wzrasta synteza interleukiny 5 (IL-5), a także interleukiny 10 (IL-10). Proces ten jest najprawdopodobniej wynikiem aktywacji współczulnego układu nerwowego przez stres oksydacyjny (Meisel i Meisel, 2011; Członkowska i wsp., 1979). Supresja układu immunologicznego jest przyczyną występujących u pacjentów po udarze powikłań infekcyjnych (Koennecke i wsp., 2011).

\section{Leki o działaniu przeciwzapalnym}

\section{Profilaktyka miażdżycy i jej powikłań}

Przeprowadzone dotychczas badania dowodzą, że leczenie stanu zapalnego może być obiecującą strategią zmniejszania ryzyka rozwoju miażdżycy i jej powikłań.

Zastosowanie terapii przeciwzapalnej canakinumabem (przeciwciałem monoklonalnym neutralizującym interleukinę $1 \beta)$ u pacjentów z przewlekłym procesem zapalnym (wysokoczułe CRP $>2 \mathrm{mg} / \mathrm{l}$ ), bez ewidentnego tła infekcyjnego czy nowotworowego, po ostrym zawale mięśnia sercowego (badanie CANTOS - Canakinumab Anti-inflammatory Thrombosis Outcomes Study) w znaczącym stopniu obniżało ryzyko poważnych epizodów sercowo-naczyniowych w porównaniu z placebo. Lek przez swoje oddziaływanie na IL-1 $\beta$, będącą głównym motorem reakcji zapalnej, zmniejszał poziom parametrów zapalnych, tj. CRP, fibrynogenu i IL-6. Warto podkreślić, że canakinumab nie obniża stężenia lipidów, tak więc zmniejszenie ryzyka sercowo-naczyniowego jest w tym przypadku efektem wyłącznie wygaszania reakcji zapalnych (Ridker i wsp., 2017).

Kolejną substancją wykazującą działanie przeciwzapalne jest kolchicyna, stosowana do tej pory w leczeniu 
dny moczanowej, choroby Behৎeta i rodzinnej gorączki śródziemnomorskiej. Kolchicyna hamuje aktywacje kriopiryny (LRR and PYD domains-containing protein 3, NLRP3), zmniejszając aktywność IL-1 $\beta$, IL-6 i innych cytokin prozapalnych, a przez wiązanie $\mathrm{z}$ tubuliną hamuje także tworzenie mikrotubul, ograniczając podziały i migrację komórek zapalnych (Leung i wsp., 2015).

W badaniu klinicznym COLCOT (Colchicine Cardiovascular Outcomes Trial) oceniano skuteczność kolchicyny w małej dawce (0,5 mg/dobę) w zapobieganiu poważnym incydentom sercowo-naczyniowym po zawale mięśnia sercowego. Jako główny punkt końcowy uznawano zgon z przyczyn sercowo-naczyniowych, zatrzymanie akcji serca, zawał mięśnia sercowego, udar mózgu oraz hospitalizację w celu rewaskularyzacji naczyń wieńcowych. Stosowanie kolchicyny wiązało się z całościowym zmniejszeniem ryzyka względnego wystąpienia wyżej wymienionych zdarzeń, ze znacznym zmniejszeniem ryzyka względnego wystąpienia udarów mózgu (Tardif i wsp., 2019).

Aktualnie trwa badanie CONVINCE (Colchicine for PreventioN of Vascular Inflammation in Non-Cardio Embolic Stroke) z zastosowaniem małej dawki kolchicyny (0,5 mg/dobę) w profilaktyce wtórnej zdarzeń naczyniowych (udarów niedokrwiennych mózgu, zawału serca, niestabilnej dławicy piersiowej, zatrzymania akcji serca lub śmierci poniesionej w wyniku ww. chorób). Do badania zaplanowano włączenie 3154 pacjentów w wieku powyżej 40 lat, u których wystąpił przemijający epizod niedokrwienny wysokiego ryzyka lub udar niedokrwienny, co spowodowane było zwężeniem tętnicy lub powstało w niejasnym mechanizmie (udar kryptogenny). Zakończenie badania, po obserwacji pacjentów przez 3 lata, zaplanowano na 2023 rok (Kelly i wsp., 2020).

\section{Udar mózgu}

Przeprowadzono także kilka badań z zastosowaniem leków immunomodulujących w ostrym stadium udaru niedokrwiennego mózgu w celu ograniczenia rozwoju ogniska udarowego.

Jednym z tych leków był enlimomab - przeciwciało przeciwko międzykomórkowej molekule adhezyjnej (intercellular adhesion molecule, ICAM-1), które zmniejszało adhezję leukocytów oraz objętość zawału mózgu w modelach na gryzoniach. Nie przyniosło jednak oczekiwanych efektów w badaniu klinicznym, w którym wzięło udział łącznie 625 pacjentów z udarem niedokrwiennym mózgu. W grupie osób, które przyjmowały lek, odnotowano wyższą śmiertelność, wyższą punktację w skali mRS po 90 dniach od wystąpienia udaru, rzadziej obserwowano całkowite ustąpienie objawów neurologicznych, częściej natomiast występowały zdarzenia niepożądane, głównie w postaci infekcji oraz gorączki (Sherman i wsp., 2001).

Z kolei badanie klinicznie ASTIN (Acute Stroke Therapy by Inhibition of Neutrophils) oceniało efekt czynnika hamującego neutrofile (UK-279, 276) u osób z udarem niedokrwiennym mózgu. Włączono do niego 966 pacjentów. Badanie zostało przerwane ze względu na brak efektów terapeutycznych po podaniu badanego leku (Krams i wsp., 2003).

Chociaż badania opublikowane na początku XXI wieku nie przynosiły pozytywnych wyników, po kilku latach powrócono do badań nad zastosowaniem nowych cząsteczek. W 2014 roku opublikowano wyniki badania z fingolimodem - nieselektywnym modulatorem receptora sfingozyno-1-fosforanu (S1P) (Fu i wsp., 2014). Fingolimod zapobiega wydostawaniu się limfocytów z węzłów chłonnych, a w badaniach doświadczalnych wykazano, że ogranicza infiltrację limfocytów do miąższu mózgu oraz hamuje lokalną aktywację mikrogleju i makrofagów. Zmniejsza przez to obrzęk wokół rdzenia udaru i w konsekwencji ogranicza ostateczny rozmiar ogniska niedokrwiennego. W przeprowadzonym w 2014 roku pilotażowym badaniu oceniono efekty podania fingolimodu u pacjentów z udarem niedokrwiennym mózgu. Do badania włączono 22 pacjentów, którzy zostali przyjęci do szpitala powyżej 4,5 godziny, ale nie później niż 72 godziny od wystąpienia udaru. U pacjentów, którzy otrzymali lek, częściej obserwowano poprawę stanu neurologicznego, a w badaniach laboratoryjnych stwierdzano mniejszą liczbę krążących leukocytów we krwi w porównaniu z grupą kontrolną. Nie zaobserwowano poważnych powikłań po zastosowaniu fingolimodu. Lek wymaga dalszych badań na większej grupie pacjentów.

Zmniejszenie napływu limfocytów do miąższu mózgu może przynosić pozytywne efekty nie tylko w udarze niedokrwiennym mózgu, ale prawdopodobnie także w leczeniu krwotoków śródmózgowych. W badaniach przeprowadzonych na myszach stwierdzono zmniejszenie obrzęku i deficytu neurologicznego oraz zwiększone przeżycie u gryzoni, u których stosowano siponimod (Bobinger i wsp., 2019). Siponimod, lek o nazwie kodowej BAF312, jest selektywnym modulatorem dwóch spośród pięciu receptorów S1P - S1PR1 oraz S1PR5, wykazującym podobne działanie do fingolimodu, ale dzięki większej selektywności o działaniu skoncentrowanym na białych krwinkach, co powoduje jego większe bezpieczeństwo stosowania przy zachowaniu podobnego profilu korzyści. Aktualnie trwa badanie z podaniem siponimodu (Efficacy, Safety and Tolerability of BAF312 Compared to Placebo in Patients With Intracerebral Hemorrhage) u pacjentów ze spontanicznym nadnamiotowym krwotokiem śródmózgowym. Zaplanowano włączenie około 60 pacjentów w wieku 18-85 lat. Lek będzie podawany przez około 14 dni, początkowo dożylnie, a następnie doustnie. Po tym czasie oceniony zostanie obrzęk mózgu towarzyszący krwotokowi jako pierwszorzędowy punkt końcowy oraz stężenie siponimodu we krwi jako punkt drugorzędowy. Zakończenie badania zaplanowano na listopad 2021 roku (www.clinicaltrials.gov/ct2/show/NCT03338998).

Kolejnym lekiem budzącym zainteresowanie jest natalizumab. Jest on przeciwciałem monoklonalnym 
skierowanym przeciwko podjednostce a4 cząsteczki adhezyjnej (very late antigen-4, VLA-4) i powoduje zmniejszenie migracji leukocytów przez śródbłonek naczyniowy. Jak wykazało badanie ACTION, choć natalizumab nie ograniczał objętości ogniska niedokrwiennego oraz nie wpływał na otrzymaną przez pacjenta punktację w skali NIHSS, to poprawiał funkcje poznawcze i zmniejszał stopień niepełnosprawności, co było oceniane po 90 dniach od zachorowania. Badanie to przeprowadzono na grupie 161 pacjentów w wieku 18-85 lat (Elkins i wsp., 2017). Zastosowanie natalizumabu w leczeniu ostrego udaru niedokrwiennego mózgu wymaga dalszych badań.

Innym lekiem hamującym aktywację komórek zapalnych i ich napływ do ośrodkowego układu nerwowego jest fisetyna (bioaktywny flawonoid). W badaniu kliniczny dotyczącym zastosowania fisetyny jednocześnie z aktywatorem plazminogenu tkankowego (rt-PA) w leczeniu ostrego udaru niedokrwiennego wykazano, że fisetyna radykalnie poprawiła wyniki leczenia pacjentów. Aż 42,5\% pacjentów uzyskało od 0 do 10 punktów w skali NIHSS w 7. dniu po zastosowaniu leczenia łączonego (fisetyna + rtPA) w czasie 3-5 godzin od momentu zachorowania, podczas gdy w grupie leczonej samym rtPA podobną punktację uzyskało 32,3\% pacjentów. Poza tym w grupie leczonej fisetyną z rtPA odnotowano także mniejszy odsetek pacjentów z NIHSS powyżej 20 (19,4\% vs $39,7 \%$ ). Korzystny wpływ fisetyny był prawdopodobnie związany ze zmniejszaniem poziomu metaloproteinaz 2 i 9 (MMP-2, MMP-9) oraz CRP w surowicy, o czym świadczą silne korelacje liniowe między poziomami tych markerów w surowicy a wynikami NIHSS u wszystkich włączonych do badania pacjentów (Wang i wsp., 2019).

Ludzki rekombinowany antagonista receptora interleukiny 1 (ILlra) dzięki właściwościom przeciwzapalnym może również okazać się dobrym środkiem terapeutycznym do zastosowania w leczeniu udaru mózgu. W badaniach na gryzoniach z indukowaną niedrożnością tętnicy środkowej mózgu wykazano, że zarówno nadekspresja ILlra, jak i podawanie ILlra dokomorowo lub do naczyń obwodowych, znacznie zmniejszały objętość zawału, obrzęk, aktywację glejową i naciekanie mózgu obwodowymi komórkami krwi. Zwierzęta poddane terapii ILlra osiągały również lepsze wyniki behawioralne (Pradillo i wsp., 2012). U ludzi agonista receptora IL-1 jest kodowany przez polimorficzny gen IL-1RN zlokalizowany na chromosomie 2 . W niedawno przeprowadzonych badaniach wykazano, że pacjenci homozygotyczni dla allelu *2 IL-1RN mieli lepsze wyniki poprawy neurologicznej i funkcjonalnej po 7 dniach do 1 roku od wystąpienia udaru niedokrwiennego mózgu w porównaniu z pacjentami z pozostałymi genotypami. Spowodowane to było najprawdopodobniej większą syntezą antagonisty receptora IL-1 (IL1ra) w monocytach i mikrogleju homozygot
IL1RN*2/IL1RN*2, co może hamować reakcję zapalną oraz w konsekwencji zmniejszać wtórne uszkodzenie mózgu. Biorąc pod uwagę uwarunkowania genetyczne, przynajmniej część pacjentów mogłaby potencjalnie odnieść korzyść z zastosowania ludzkiego rekombinowanego antagonisty receptora IL-1 w ostrej fazie udaru niedokrwiennego mózgu (Gromadzka i wsp., 2007).

\section{Przeciwdziałanie immunosupresji}

Ze względu na wysoką liczbę zakażeń (zwłaszcza dotyczących układu oddechowego i moczowego) u pacjentów z udarem mózgu podejmowano próby wykorzystania antybiotyków, $\beta$-blokerów (Barer i wsp., 1988; Dziedzic i wsp., 2007, Chamorro i wsp., 2005) oraz immunoglobulin (IVIG) w profilaktyce tych zakażeń. W jednym z badań na grupie 71 pacjentów wykazano, że podawanie IVIG do 5 dni od wystąpienia udaru niedokrwiennego mózgu powodowało zmniejszenie śmiertelności związanej z infekcjami, w szczególności związanej z zapaleniem płuc. Największe korzyści odnosili pacjenci z niższym stężeniem immunoglobulin we krwi (<600 mg/dl) (Palasik i wsp., 1999). Aktualnie trwa także randomizowane kontrolowane badanie kliniczne PRECIOUS (PREvention of Complications to Improve OUtcome in elderly patients with acute Stroke) mające ocenić skuteczność kombinacji ceftriaksonu, paracetamolu oraz metoklopramidu w prewencji infekcji, zachłyśnięcia oraz gorączki po udarze niedokrwiennym lub krwotocznym mózgu. Leki te zgodnie z protokołem badania powinny być zastosowane do 24 godzin i utrzymane przez 96 godzin od czasu zachorowania. Zaplanowano włączenie 3800 pacjentów w wieku powyżej 66 lat, u których zespół neurologiczny oceniany w skali NIHSS wyniesie 6 lub więcej, a stopień niepełnosprawności przed udarem był mniejszy niż 4 w mRS (modified Rankin Scale). Datę zakończenia badania PRECIOUS ustalono na 31 maja 2020 roku (Reinink i wsp., 2018).

\section{Podsumowanie}

Kolejne badania doświadczalne i kliniczne pokazują, jak istotną rolę pełnią komórki zapalne oraz wytwarzane przez nie cząsteczki w rozwoju i przebiegu udarów mózgu. Wciąż nie mamy jednak pewności, jak zewnętrzne modulowanie reakcji zapalnej w udarze może wpływać na końcowe wyniki leczenia. Choć leki przeciwzapalne stanowią niewątpliwie kuszącą perspektywę w leczeniu ostrej i podostrej fazy udarów niedokrwiennych mózgu, należy pamiętać o ryzyku pogłębienia naturalnie występującej w udarze immunosupresji i związanych z nią powikłań infekcyjnych. 
Conflict of interest and financial support non declared. / Nie zgłoszono konfliktu interesów oraz dofinansowania.

The work described in this article has been carried out in accordance with The Code of Ethics of the World Medical Association (Declaration of Helsinki) for experiments involving humans, EU Directive 2010/63/EU for animal experiments, and Uniform Requirements for manuscripts submitted to biomedical journals. / Treści przedstawione w artykule są zgodne z zasadami Deklaracji Helsińskiej, dyrektywami EU oraz ujednoliconymi wymaganiami dla czasopism biomedycznych.

AK-D - data collection and interpretation, preparation of the article, literature search, figures / zebranie danych i ich interpretacja, przygotowanie pracy, zebranie piśmiennictwa, ryciny; MŚ - data collection and interpretation, preparation of the article, literature search / zebranie danych i ich interpretacja, przygotowanie pracy, zebranie piśmiennictwa; AC - basic conceptual work, critical reviewing, literature search, acceptance of the final article version / zasadniczy wkład w koncepcję i projekt pracy, krytyczne zrecenzowanie pod kątem istotnej zawartości intelektualnej, zebranie piśmiennictwa, akceptacja ostatecznej wersji do opublikowania

\section{References / Piśmiennictwo}

1. Amento EP, Ehsani N, Palmer H, Libby P. Cytokines and growth factors positively and negatively regulate interstitial collagen gene expression in human vascular smooth muscle cells. Arterioscler Thromb 1991; 11 (5): 1223-1230.

2. Anrather J, Iadecola C. Inflammation and Stroke: An Overview. Neurotherapeutics 2016; 13: 661-670.

3. Banach M, Markuszewski L, Grzegorczyk J, Jegier B. Rola zapalenia w patogenezie miażdżycy. Przegl Epidemiol 2004; 58: 663-670.

4. Barer DH, Cruickshank JM, Ebrahim SB, Mitchell JRA. Low dose $\beta$ blockade in acute stroke ("BEST" trial): An evaluation. Br Med J (Clin Res Ed) 1988; 296(6624): 737-741.

5. Barreto GE, White RE, Ouyang Y, Xu L, Giffard RG. Astrocytes: Targets for Neuroprotection in Stroke. Cent Nerv Syst Agents Med Chem 2012; 11: 164-173.

6. Basic Kes V, Simundic AM, Nikolac N, Topic E, Demarin V. Pro-inflammatory and anti-inflammatory cytokines in acute ischemic stroke and their relation to early neurological deficit and stroke outcome. Clin Biochem 2008; 41(16-17): 1330-1334.

7. Bobinger T, Manaenko A, Burkardt P, Beuscher V, Sprügel MI, Roeder SS et al. Siponimod (BAF-312) Attenuates Perihemorrhagic Edema And Improves Survival in Experimental Intracerebral Hemorrhage. Stroke 2019; 50 (11): 3246-3254.

8. Całkosiński I, Dobrzyński M, Całkosińska M, Seweryn E, Bronowicka-Szydełko A, Dzierzba K et al. Charakterystyka odczynu zapalnego. Postępy Hig Med Dosw 2009; 63: 395-408.

9. Chamorro A, Horcajada JP, Obach V, Vargas M, Revilla M, Torres $\mathrm{F}$ et al. The early systemic prophylaxis of in-fection after stroke study: a randomized clinical trial. Stroke 2005; 36(7): 1495-1500.

10. Członkowska A, Cyrta B, Korlak J. Immunological observations on patients with acute cerebral vascular disease. J Neurol Sci 1979; 43(3): 455-464.

11. d'Audigier C, Cochain C, Rossi E, Guérin CL, Bie 'che I, Blandinie 'res A et al. Thrombin receptor PAR-1 activation on endothelial progenitorcells enhances chemotaxis-associated genes expressionand leukocyte recruitment by a COX-2-dependent mechanism. Angiogenesis 2015; 18: 347-359.

12. Dziedzic T, Slowik A, Pera J, Szczudlik A. Beta-blockers reduce the risk of early death in ischemic stroke. J Neurol Sci 2007; 252(1): 53-56.

13. Elkins J, Veltkamp R, Montaner J, Johnston SC, Singhal AB, Becker Ket al. Safety and efficacy of natalizumab in patients with acute ischaemic stroke (ACTION): a randomised, placebo-controlled, double-blind phase 2 trial. Lancet Neurol 2017; 16(3): 217-226.

14. Ercan M, Firtina S, Konukoglu D. Comparison of plasma viscosity as a marker of endothelial dysfunction with nitric oxide and asymmetric dimethylarginine in subjects with dyslipidemia. Clin. Hemorheol Microcirc 2014; 57(4): 315-323.

15. Fu Y, Liu Q, Anrather J, Shi FD. Immune interventions in stroke. Nat Rev Neurol 2015; 11: 524-535.

16. Fu Y, Zhang N, Ren L, Yan Y, Sun N, Li YJ et al. Impact of an immune modulator fingolimod on acute ischemic stroke. Proc Natl Acad Sci U S A 2014; 111 (51): 18315-18320.

17. Gromadzka G, Sarzynska-Dlugosz I, Czlonkowska A. IL1RN intron 2 polymorphism caused by variable number tandem repeats is associated with 1-year outcome in patients with ischaemic stroke. J Neurol Neurosurg Psychiatry 2007; 78(2): 183-186.

18. Jarząbek K, Sobczyk A, Sobczyk W, Łabuzek K, Belowski D, Gabryel B. Koncepcja niestabilnej blaszki miażdżycowej i farmakologiczne strategie terapeutyczne. Chirurgia Polska 2015; 17(1-2): 49-68.

19. Jenny NS, Callas PW, Judd SE, McClure LA, Kissela B, Zakai NA et al. Inflammatory cytokines and ischemic stroke risk: The REGARDS cohort. Neurol 2019; 92(20): 2375-2384.

20. Karliński M, Bembenek J, Grabska K, Kobayashi A, Baranowska A, Litwin T et al. Routine serum C-reactive protein and stroke outcome after intravenous thrombolysis. Acta Neurol Scand 2014; 130: 305-311.

21. Kelly P, Weimar C, Lemmens R, Murphy S, Purroy F, Arsovska A, NM Bornstein et.al. Colchicine for prevention of vascular inflammation in Non-CardioEmbolic stroke (CONVINCE) study protocol for a randomised controlled trial. Eur Stroke J 2020; 0: 1-7.

22. Koennecke HC, Belz W, Berfelde D, Endres M, Fitzek S, Hamiltonet $\mathrm{F}$ et al. Factors influencing in-hospital mortality and morbidity in patients treated on a stroke unit. Neurology 2011; 77: 965-972.

23. Krams M, Lees KR, Hacke W, Grieve AP, Orgogozo JM, Ford GA. Acute Stroke Therapy by Inhibition of Neutrophils (ASTIN): An Adaptive Dose-Response Study of UK-279,276 in Acute Ischemic Stroke. Stroke 2003; 34: 2543-2548.

24. Kranzhofer R, Schmidt J, Pfeiffer CA, Hagl S, Libby P, Kübler W. Angiotensin induces inflammatory activation of human vascular smooth muscle cells. Arterioscler Thromb Vasc Biol 1999; 19: 1623-1629.

25. Leung YY, Yao Hui LL, Kraus VB. Colchicine-Update on mechanisms of action and therapeutic uses. Semin Arthritis Rheum 2015; 45(3): 341-350.

26. Libby P, Ridker P, Maseri A. Inflammation and Atherosclerosis. Circulation 2002; 105: 1135-1143.

27. Machado-Pereira M, Santos T, Ferreira L, Bernardino L, Ferreira R. Anti-Inflammatory Strategy for M2 Microglial Polarization Using Retinoic Acid-Loaded Nanoparticles. Mediat Inflamm 2017; 2017 (Article: 6742427): 1-11.

28. Maestrini I, Strbian D, Gautier S, Haapaniemi E, Moulin S, Sairanen T et al. Higher neutrophil counts before 
thrombolysis for cerebral ischemia predict worse outcomes. Neurol 2015; 85(16): 1408-1416.

29. Majid A. Neuroprotection in Stroke: Past, Present, and Future. ISRN Neurology 2014; 2014 (Article: 515716): 1-17.

30. Manduteanu I, Simionescu M. Inflammation in atherosclerosis: A cause or a result of vascular disorders? J Cell Mol Med 2012; 16: 1978-1990.

31. Meisel C, Meisel A. Suppressing immunosuppression after stroke. N Eng J Med 2011; 365(22): 2134-2136.

32. Mertens JC, Leenaerts D, Brouns R, Engelborghs S, Leven $\mathrm{M}$, De Deyn PP et al. Procarboxypeptidase U (proCPU, TAFI, proCPB2) in cerebrospinal fluid during ischemic stroke is associated with stroke progression, outcome and blood-brain barrier dysfunction. J Thromb Haemost 2018; 16: 342-348.

33. Montaner J, Fernandez-Cadenas I, Molina CA, Ribo M, Huertas R, Rosell A et al. Poststroke C-reactive protein is a powerful prognostic tool among candidates for thrombolysis. Stroke 2006; 37: 1205-1210.

34. Morris RS, Jones PS, Alawneh JA, Hong YT, Fryer TD, Aigbirhio FI et al. Relationships between selective neuronal loss and microglial activation after ischaemic stroke in man. Brain 2018; 141: 2098-2111.

35. Mracsko E, Veltkamp R. Neuroinflammation after intracerebral hemorrhage. Front Cell Neurosci 2014; 8(Article 388): 1-13.

36. Palasik W, Popow J, Lechowicz W, Fiszer U, Czlonkowska A. Prophylactic administration of intravenous immunoglobulins in the early stage of ischemic stroke. Med Sci Monit 1999; 5(3): 528-532.

37. Pasierski T, Andziak P. Rozwój i regresja miażdżycy. W: Angiologia. Pasierski T, Gaciong Z, Torbicki A, Szmidt J (red.) Wyd. Lekarskie PZWL 2004; 50-58.

38. Pradillo JM, Denes A, Greenhalgh AD, Boutin H, Drake C, McColl BW et al. Delayed administration of interleukin-1 receptor antagonist reduces ischemic brain damage and inflammation in comorbid rats. J Cereb Blood Flow Metab 2012; 32(9): 1810-1819.

39. Reinink H, de Jonge JC, Bath PM, van de Beek D, Berge E, Borregaard S et al. PRECIOUS: PREvention of Complications to Improve OUtcome in elderly patients with acute Stroke. Rationale and design of a randomised, open, phase III, clinical trial with blinded outcome assessment. Eur Stroke J 2018; 3: 291-298.

40. Ridker PM, Everett BM, Thuren T, MacFadyen JG, Chang WH, Ballantyne C et al. Antiinflammatory therapy with canakinumab for atherosclerotic disease. N Eng J Med 2017; 377(12): 1119-1131.
41. Ross R. Atherosclerosis - An inflammatory disease. N Engl J Med 1999; 340: 115-126.

42. Sherman D, Bes A, Easton JD, Hacke W, Kaste M, Polmar SH et al. Use of anti-ICAM-1 therapy in ischemic stroke: Results of the enlimomab acute stroke trial. Neurology 2001; 57: 1428-1434.

43. Shi K, Tian DC, Li ZG, Ducruet AF, Lawton MT, Shi FD. Global brain inflammation in stroke. Lancet Neurol 2019; 18: 1058-1066.

44. Schroeter M, Schiene K, Kraemer M, Hagemann G, Weigel $\mathrm{H}$, Eysel UT et al. Astroglial responses in photochemically induced focal ischemia of the rat cortex. Exp Brain Res 1995; 106: 1-6.

45. Shichita T, Hasegawa E, Kimura A, Morita R, Sakaguchi R, Takada I et al. Peroxiredoxin family proteins are key initiators of post-ischemic inflammation in the brain. Nat Med 2012; 18(6): 911-917.

46. Stoll G, Nieswandt B. Thrombo-inflammation in acute ischaemic stroke - implications for treatment. Nat Rev Neurol 2019; 15(8): 473-481.

47. Tardif JC, Kouz S, Waters DD, Bertrand OF, Diaz R, Maggioni AP et al. Efficacy and safety of low-dose colchicine after myocardial infarction. N Eng J Med 2019; 381(26): 2497-2505.

48. Tarkin JM, Joshi FR, Rudd JHF. PET imaging of inflammation in atherosclerosis. Nat Rev Cardiol 2014; 11: 443-457.

49. Thiel A, Radlinska BA, Paquette C, Sidel M, Soucy JP, Schirrmacher $\mathrm{R}$ et al. The temporal dynamics of poststroke neuroinflammation: a longitudinal diffusion tensor imaging-guided PET study with 11C-PK11195 in acute subcortical stroke. J Nucl Med 2010; 51: 1404-1412.

50. Tiainen M, Mereroja A, Strabin D, Suvanto J, Curtze S, Lindsberg PJ et al. Body temperature, blood infection parameters, and outcome of thrombolysis-treated ischemic stroke patients. Int J Stroke 2013; 8: 632-638.

51. Wang L, Cao D, Wu H, Jia H, Yang C, Zhang L. Fisetin Prolongs Therapy Window of Brain Ischemic Stroke Using Tissue Plasminogen Activator: A Double-Blind Randomized Placebo-Controlled Clinical Trial. Clin and Appl Thromb Hemost 2019; 25: 1-8.

52. Yudkin JS, Stehouwer CD, Emeis JJ, Coppack W. C-reactive protein in healthy subjects: associations with obesity, insulin resistance, and endothelial dysfunction: a potential role for cytokines originating from adipose tissue? Arterioscler Thromb Vasc Biol 1999; 19: 972-978.

53. Zhang J, Ren Q Song Y, He M, Zeng Y, Liu Z et al. Prognostic role of neutrophil-lymphocyte ratio in patients with acute ischemic stroke. Medicine (Baltimore) 2017; 2017; 96(45): e8624. 